\title{
Costimulation Blockade in Kidney Transplant Recipients
}

\author{
Marieke van der Zwan ${ }^{1,2,3}$ (D) Dennis A. Hesselink ${ }^{1,2} \cdot$ Martijn W. F. van den Hoogen ${ }^{1,2} \cdot$ Carla C. Baan $^{1,2}$
}

Published online: 20 November 2019

(c) The Author(s) 2019

\begin{abstract}
Costimulation between $\mathrm{T}$ cells and antigen-presenting cells is essential for the regulation of an effective alloimmune response and is not targeted with the conventional immunosuppressive therapy after kidney transplantation. Costimulation blockade therapy with biologicals allows precise targeting of the immune response but without non-immune adverse events. Multiple costimulation blockade approaches have been developed that inhibit the alloimmune response in kidney transplant recipients with varying degrees of success. Belatacept, an immunosuppressive drug that selectively targets the CD28-CD80/CD86 pathway, is the only costimulation blockade therapy that is currently approved for kidney transplant recipients. In the last decade, belatacept therapy has been shown to be a promising therapy in subgroups of kidney transplant recipients; however, the widespread use of belatacept has been tempered by an increased risk of acute kidney transplant rejection. The purpose of this review is to provide an overview of the costimulation blockade therapies that are currently in use or being developed for kidney transplant indications.
\end{abstract}

\section{Introduction}

Kidney transplant recipients (KTRs) require lifelong immunosuppressive therapy to prevent acute kidney transplant rejection (AR). Currently, the standard immunosuppressive regimen consists of induction therapy (either a $\mathrm{T}$ celldepleting agent or basiliximab, an antibody directed against the interleukin [IL]-2 receptor), followed by maintenance therapy consisting of a calcineurin inhibitor (CNI; either tacrolimus or ciclosporin) and mycophenolic acid (MPA) with or without glucocorticoids [1-4]. Although transplantation is a success story of modern medicine, the long-term allograft and patient survival are influenced by the toxicity of CNIs, which include infections, malignancies, metabolic adverse effects, nephrotoxicity, and neurotoxicity [5-7]. Another limitation of current immunosuppression is that it

Marieke van der Zwan

m.vanderzwan@erasmusmc.nl

1 Division of Nephrology and Transplantation, Department of Internal Medicine, Erasmus MC, University Medical Center Rotterdam, Rotterdam, The Netherlands

2 Rotterdam Transplant Group, Erasmus MC, University Medical Center Rotterdam, Rotterdam, The Netherlands

3 Division of Nephrology and Kidney Transplantation, Department of Internal Medicine, Rotterdam Transplant Group, Erasmus MC, University Medical Center Rotterdam, Room Na-524, P.O. Box 2040, 3000 CA Rotterdam, The Netherlands is a 'one size fits all' therapy and is not tailored to the individual needs of a KTR. Therefore, novel and personalized therapeutic strategies have to be developed.

Several approaches have been investigated to limit the adverse effects of CNIs, including monitoring of CNI concentrations to guide dosing, and CNI-sparing regimens. Examples of the latter are CNI minimization, CNI withdrawal, $\mathrm{CNI}$ conversion to alternative immunosuppressive agents, and, lastly, CNI avoidance from the time of the transplantation with substitution of an alternative immunosuppressive drug [8]. However, many such trials failed because they resulted in unacceptably high incidences of AR and toxicity, or an increased incidence of infections associated with the alternative immunosuppressants [9-15].

Costimulation is essential for the regulation of an effective alloimmune response. The costimulatory pathway is not targeted with the conventional immunosuppressive therapy. Biologicals that intervene with the costimulatory pathway may allow more precise targeting of the immune response without causing non-immune adverse events. Belatacept, a fusion protein composed of a crystallizable fragment $(\mathrm{Fc})$ of immunoglobulin ( $\mathrm{Ig}$ ) G1 and the extracellular domain of cytotoxic T lymphocyte protein 4 (CTLA4), is the only costimulation blockade therapy that is currently approved for the prevention of rejection after kidney transplantation $[16,17]$. Belatacept is well-tolerated and its use is associated with an improved allograft function compared with CNI in certain subgroups of KTRs [18, 19]; however, belatacept 


\section{Key Points}

Multiple costimulation blockade drugs have been developed and tested in kidney transplant recipients. Belatacept, a biological that inhibits the interaction between antigen CD28 and CD80/86, is the only costimulation blockade drug that is currently approved for the prevention of kidney transplant rejection.

Belatacept is well-tolerated and is associated with a better allograft function compared with calcineurin inhibitors. A reason for concern is the higher risk of acute kidney transplant rejection compared with current standard immunosuppressive therapy.

Optimization of the selection of patients with a low risk for belatacept-resistant rejection in combination with new treatment strategies is necessary to expand the use of belatacept in the future.

The safety and efficacy of several other biologicals that target costimulation pathways (i.e. CD28 and CD40) are currently being investigated for kidney transplantation.

may not be the game changer it was hoped to be due to a high risk of AR [20]. In this review, the current applications of biologicals that target costimulation pathways in kidney transplantation are discussed, including the current status and future strategies of belatacept therapy.

\section{Costimulation}

The process of T-cell activation is a complex cascade consisting of three signals. First, alloantigens from the allograft are taken up by antigen-presenting cells (APCs; dendritic cells, macrophages, and B cells), which then home to the draining lymph nodes. In the lymph nodes, the alloantigens are presented on the surface of APCs by human leucocyte antigen (HLA) molecules. In humans, the T-cell receptor (TCR) on naive T cells is activated after interaction with the alloantigen/HLA complex, which is also known as signal 1 (Fig. 1). A costimulatory signal (signal 2) is necessary to achieve full activation of T cells. Several cell-surface proteins (costimulatory ligands) on APCs interact with their complementary receptors on naive T cells (Fig. 1). Signal 2 represents a combination of positive and negative signals that regulate the outcome of the HLA/TCR. Without this signal, naive T cells will undergo apoptotic cell death [21-23].

Two costimulatory pathways are critical for T-cell activation: (1) the Ig superfamily (e.g. CD28 [T-cell-specific surface glycoprotein CD28] family), the CD2/signaling lymphocytic activation molecule (SLAM) family, and the
T-cell/transmembrane, Ig, and mucin (TIM) family; and (2) the TNF (tumor necrosis factor)/TNF receptor superfamily (Fig. 1) [21].

Signal 3 is formed by cytokines and the (increased) expression of cytokine receptors, such as the IL-2 receptor $\alpha$-chain (CD25) (Fig. 1). Activation of CD25 will activate intracellular signaling pathways downstream of the TCR, including the mitogen-activated protein kinase (MAPK), calcineurin, and PI3 K pathways, followed by the activation of transcription factors that regulate the production of several cytokines (i.e. IL-2 and interferon [IFN]- $\gamma$ ) [24]. These and other cytokines promote $\mathrm{T}$-cell proliferation of diverse effector $\mathrm{CD} 4^{+} \mathrm{T}$-cell subsets and cytotoxic $\mathrm{CD} 8^{+} \mathrm{T}$ cells [25].

\section{Belatacept Therapy in Kidney Transplantation}

\subsection{Development of Belatacept}

Belatacept targets the CD28-CD80/CD86 pathway. The costimulation molecule CD28 is a surface receptor that is constitutively expressed on T cells (Fig. 1). The inhibitory receptor CTLA4 is localized in intracellular vesicles in resting $T$ cells and is expressed on the cell surface $48-72 \mathrm{~h}$ after T-cell activation. CTLA4 binds to CD80 and CD86 with a higher affinity than CD28 [21]. Therefore, the binding of CTLA4 to CD80/CD86 dampens the activation of T cells [26]. At birth, almost all human T cells express CD28 [27]. Aging, continuous antigenic stimulation (which can be caused by, for example, end-stage renal disease, human immunodeficiency virus infection, and auto-immune disease) and cytomegalovirus infection lead to loss of CD28 expression of T cells [27-29]. These CD28 ${ }^{-}$effector memory $\mathrm{T}$ cells have reduced costimulatory requirements and an impaired proliferative capacity, but are highly proinflammatory $[27,30]$. These cells rapidly secrete effector cytokines (i.e. TNF $\alpha$ and IFN $\gamma$ ) upon restimulation.

One of the first biologics that was designed to target the CD28-CD80/CD86 superfamily was abatacept (Fig. 1), a fusion protein composed of an $\mathrm{Fc}$ of $\mathrm{IgG1}$ and the extracellular domain of CTLA4 [31]. Because CTLA4 binds with a higher affinity to CD80/CD86 than CD28, it was hypothesized that T-cell activation could be inhibited with such a CTLA4 construct. Abatacept is approved for the treatment of rheumatoid arthritis (Fig. 2) [32], and has been tested in non-human primates transplanted with a kidney or pancreatic islets; however, alloreactivity appeared to be inhibited insufficiently [33, 34]. Therefore, the development of abatacept therapy for transplantation was discontinued and a new CTLA4-Ig construct (belatacept) was developed with increased avidity for CD80 and CD86 by changing two amino acids (L104E and A29Y) (Figs. 1 and 2) [16]. 


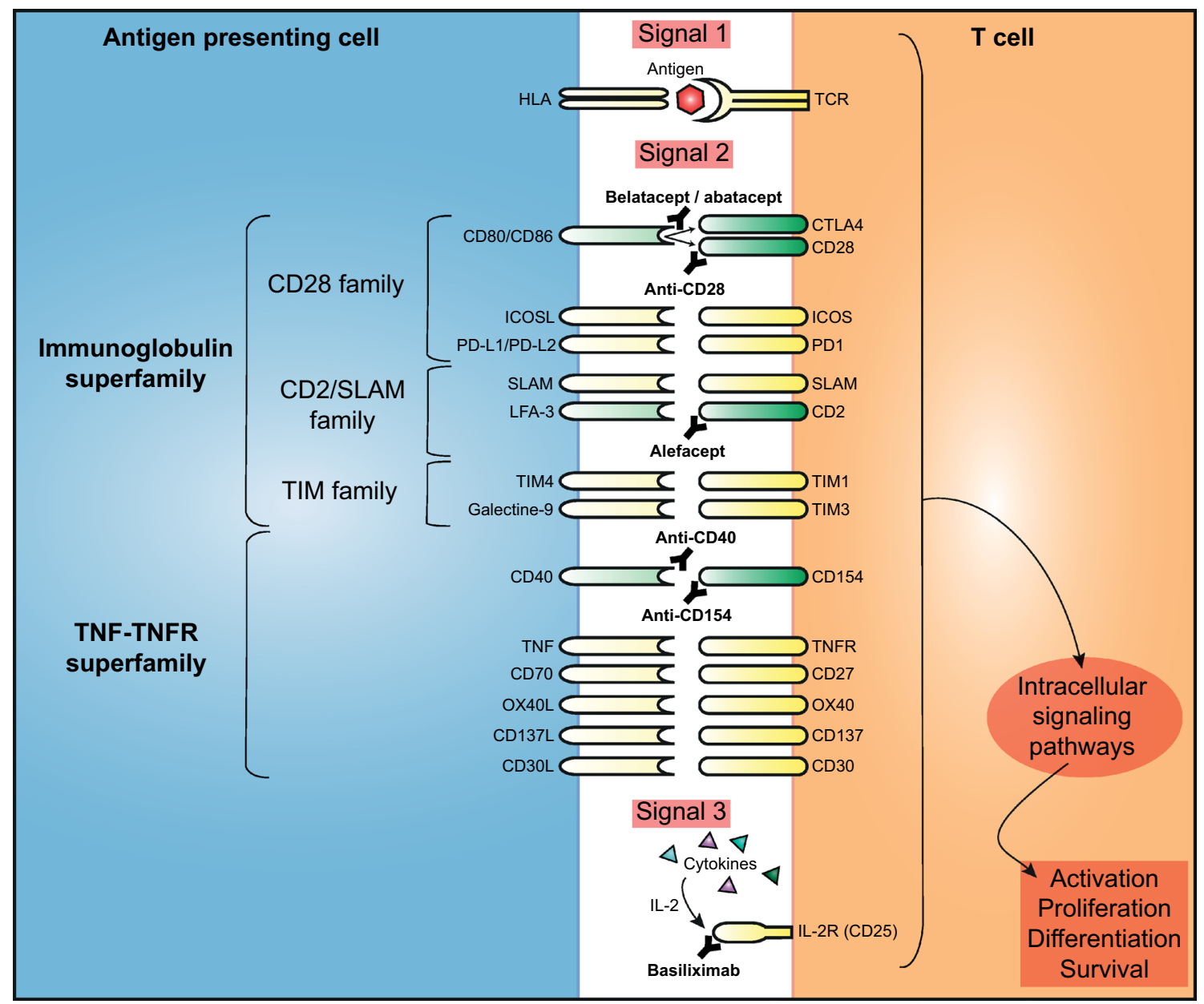

Fig. 1 Costimulation between $\mathrm{T}$ cells and antigen-presenting cells. Schematic overview of signal 1, 2 and 3 of T-cell activation. During signal 2 , costimulatory molecules on $\mathrm{T}$ cells and antigen-presenting cells interact to activate or inhibit $\mathrm{T}$ cells after alloantigen recognition. Two important groups of costimulatory molecules are presented: the immunoglobulin superfamily and the TNF/TNFR superfamily. The costimulatory molecules discussed in this review are green and the costimulatory molecules that are not discussed are yellow. Sev-

Belatacept was found to have a fourfold higher binding affinity for CD86 and a twofold higher binding affinity for CD80 compared with abatacept [16]. Although the development of abatacept in transplantation was stopped, abatacept was recently used as rescue therapy in nine KTRs with an intolerance to CNI, because belatacept was temporarily unavailable due to manufacturing problems $[35,36]$. None of the allografts were lost after a median period of 115 months and one patient experienced AR [35].

Belatacept was approved as treatment for the prevention of AR by the European Medicines Agency (EMA) and the US FDA in 2011 based on the results of two large randomized, controlled, multicenter, phase III trials (Fig. 2): The Belatacept Evaluation of Nephroprotection and Efficacy as First-line Immunosuppression (BENEFIT) study (with eral biologicals are developed that interfere with the costimulatory molecules on T cells and antigen-presenting cells. CTLA 4 cytotoxic T lymphocyte protein 4, HLA human leucocyte antigen, ICOS inducible T-cell costimulator, $P D$ programmed death, SLAM signaling lymphocytic activation molecule, TCR T-cell receptor, TIM T cell/transmembrane, immunoglobulin, and mucin, $T N F$ tumor necrosis factor, TNFR tumor necrosis factor receptor

standard criteria donors) and the BENEFIT-extended criteria donors (BENEFIT-EXT) study [17, 37, 38]. In these trials, 1264 KTRs were treated with either ciclosporin or belatacept as first-line treatment in combination with MPA and glucocorticoids. The main findings of the BENEFIT and BENEFIT-EXT studies were that the 1-year patient and allograft survival of patients treated with belatacept were similar to patients treated with ciclosporin $[37,38]$. Although the incidence of acute T-cell-mediated rejection (aTCMR) was increased in belatacept-treated patients, the kidney function was better in these patients compared with ciclosporintreated patients [37, 38]. In addition, the use of belatacept was associated with an increased risk for post-transplant lymphoproliferative disease, mostly in Epstein-Barr virus seronegative KTRs [37-39]. 


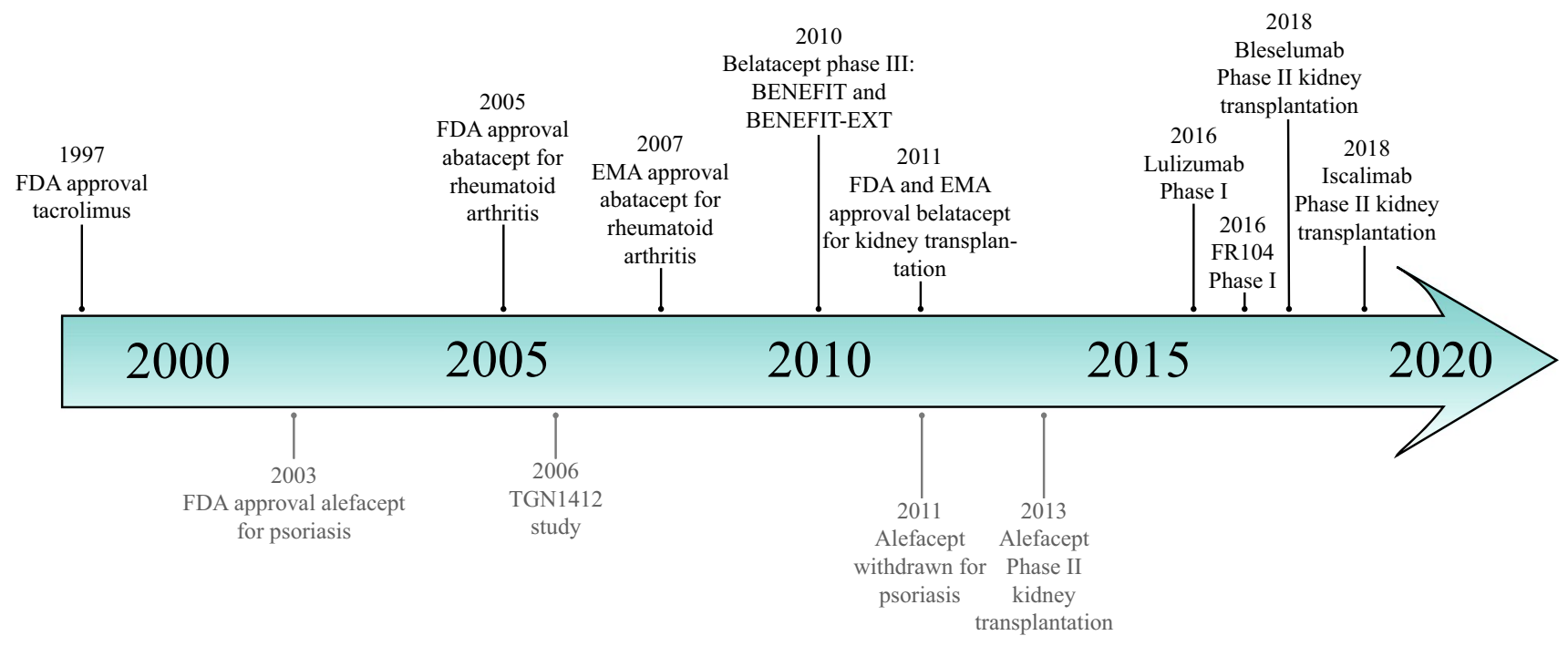

Fig. 2 Timeline of the development of costimulation blockade. The costimulation blockade drugs that are currently used or tested in kidney transplant recipients are shown in black, whereas the costimulation blockade drugs that are no longer being used or have not devel-

The safety and efficacy of belatacept were also tested in a phase II, randomized, controlled, multicenter trial in liver transplant recipients [40]. This trial randomized 260 patients between therapy with belatacept (three different belatacept regimens) or tacrolimus (two different tacrolimus regimens). The primary composite endpoint consisted of incidence of acute liver transplant rejection, graft loss, and death at 6 months after transplantation. The occurrence of the composite endpoint was higher in the belatacept groups $(42-48 \%)$ than in the tacrolimus groups (15-38\%) [40]. The results of this study were reason to discontinue further development of belatacept for liver transplantation. However, the mean estimated glomerular filtration rate (eGFR) was $15-34 \mathrm{~mL} / \mathrm{min} / 1.73 \mathrm{~m}^{2}$ higher in the liver transplant recipients treated with belatacept [40]. Therefore, liver transplant recipients with an impaired renal function could benefit from belatacept therapy. Proper selection of patients and an adjusted treatment protocol can possibly improve the results of belatacept in liver transplantation in the future [41].

\subsection{Clinical Outcomes of De Novo Use of Belatacept in Kidney Transplant Recipients}

A systematic review with meta-analysis was performed of five studies that compared treatment with belatacept with CNIs (including the BENEFIT and BENEFIT-EXT studies) in 1535 KTRs [42]. Of the 521 patients treated with a CNI, 478 patients used ciclosporin and 43 patients were treated with tacrolimus. After 3 years of treatment, no difference was seen between patients treated with either belatacept or a CNI regarding the risk of death (relative risk $0.75,95 \%$ oped for kidney transplantation are shown in grey. EMA European Medicines Agency, FDA United States Food and Drug Administration, FR104 pegylated monoclonal antibody fragment antagonist of CD28, TGN1412 CD28 humanized antibody

confidence interval $[\mathrm{CI}] 0.39-1.44 ; p=0.39)$, allograft loss (relative risk $0.91,95 \% \mathrm{CI} 0.61-1.38 ; p=0.67$ ), and incidence of aTCMR (RR 1.56, 95\% CI $0.85-2.86 ; p=0.15$ ) [42]. However, the kidney allograft function was better in patients treated with belatacept (eGFR mean difference of $9.96 \mathrm{~mL} / \mathrm{min} / 1.73 \mathrm{~m}^{2}, 95 \%$ CI $3.28-16.64 ; p=0.0035$ ). Furthermore, the use of belatacept was associated with a reduced incidence of post-transplant diabetes mellitus, better blood pressure, and a better lipid profile 1 year after therapy with belatacept [42].

In 2016, the 7-year follow-up results of the BENEFIT and BENEFIT-EXT studies were published. In these studies, the risks of death and graft loss in KTRs treated with belatacept were similar to those in KTRs treated with ciclosporin [18, 19]. Although, the risk of aTCMR was higher in belatacepttreated patients compared with ciclosporin-treated patients, their kidney function after 7 years was better. An explanation for the better kidney function may be that belatacept is associated with less interstitial inflammation and tubular atrophy compared with CNIs. Vitalone et al. compared the 1-year protocol biopsies of KTRs treated with belatacept or ciclosporin [43], and found that the biopsies of patients treated with belatacept contained less interstitial inflammation, interstitial fibrosis, and tubular atrophy, and gene expression analysis revealed a lower expression of genes involved in fibrosis and tubulointerstitial damage compared with the biopsies of patients treated with ciclosporin [43]. In another study, 10 -year protocol biopsies of 23 clinically stable KTRs treated with belatacept and 10 KTRs treated with CNI (seven taking ciclosporin and three taking tacrolimus) were analyzed [44]. The biopsies of belatacept-treated 
patients contained less interstitial inflammation and tubular atrophy, less interstitial inflammation, and less hyalinosis [44].

The 7-year follow-up studies also showed that the formation of de novo donor-specific anti-HLA antibodies (DSAs) was reduced in the belatacept-treated patients compared with the patients treated with ciclosporin $[18,19]$. A possible explanation for this observation may be that costimulation blockade with belatacept leads to more effective prevention of DSA formation by B cells and that drug adherence is better in patients treated with belatacept because of intravenous administration. The occurrence of post-transplant diabetes mellitus, blood pressure, and lipid profile were not discussed in the long-term follow-up studies of belatacept.

To conclude, these long-term outcomes demonstrate that belatacept therapy is a safe therapy for KTRs and is associated with a better kidney function and a reduced incidence of de novo DSA. Whether long-term belatacept therapy leads to a better metabolic profile than CNI therapy is not known $[18,19,39]$.

A limitation of the BENEFIT studies is that belatacept therapy was compared with ciclosporin therapy. Currently, the CNI of choice in most transplant centers is tacrolimus $[1,45]$. No large, head-to-head, randomized controlled trials have been performed that compared the outcomes of patients treated with either belatacept or tacrolimus. In our center, a trial was performed that included 40 KTRs who were randomized between first-line therapy consisting of tacrolimus or belatacept, in combination with MPA and glucocorticoids [46]. The AR incidence in the first year after transplantation was higher in belatacept-treated patients (55\% vs. $10 \% ; p=0.006$ ) [46]. Another randomized controlled trial compared three treatment regimens in KTRs: alemtuzumab induction with tacrolimus, alemtuzumab induction with belatacept, and basiliximab induction with belatacept and a 3-month course of tacrolimus [47]. This study was halted prematurely after the inclusion of 19 patients, due to a high rate of serious adverse events in belatacept-treated patients, including thrombotic complications and aTCMR [47].

The comparison between belatacept and tacrolimus therapy has also been investigated in three indirect studies [48-50]. In a single-center, retrospective analysis, the outcomes of KTRs treated with belatacept $(n=97)$ were compared with a historical cohort of patients treated with tacrolimus $(n=205)$ [48]. An increased rate of aTCMR was noted in patients treated with belatacept compared with patients treated with tacrolimus (50.5\% vs. $20.5 \%$ ) [48]. In a retrospective propensity score-matched cohort study, the outcomes of KTRs treated with either tacrolimus or belatacept were compared [49]. The risk of AR was higher in the first post-transplant year in patients treated with belatacept (odds ratio $3.12,95 \%$ CI $2.13-4.57 ; p<0.001)$ but no difference was seen in the risk of death (hazard ratio [HR] 0.84, 95\% CI $0.61-1.15 ; p=0.28$ ) or allograft loss (HR $0.83,95 \%$ CI $0.62-1.11 ; p=0.20)$ [49]. Muduma et al. performed a systematic review and meta-analysis with an indirect treatment comparison analysis between tacrolimus (both immediaterelease and prolonged-release formulations) and belatacept [50]. The AR rate was reduced in patients treated with tacrolimus compared with patients treated with belatacept (risk ratio 0.22 [95\% CI $0.13-0.39$ ] to 0.44 [95\% CI $0.20-0.99$ ]) [50]. The risks of allograft loss and death were similar between both treatments.

One of the reasons for the high risk of aTCMR after belatacept may be that the immunosuppressive function of regulatory $\mathrm{T}$ cells (Tregs) is impaired [51-55]. Tregs are dependent on signaling via CTLA4, and binding of belatacept to CD80/86 interferes with CTLA4. Therefore, the combination of belatacept with therapies that preserve Treg functionality, such as T-cell-depleting antibodies and mammalian target of rapamycin (mTOR) inhibitors could possibly lead to a reduced incidence of AR [4, 56, 57].

The combination of induction therapy with T-cell-depleting drugs and belatacept has been tested in several studies, with various outcomes. In one study, alemtuzumab induction followed by tacrolimus or belatacept led to a similar incidence of AR [58]. In another study, patients treated with T-cell-depleting induction therapy (either rabbit antithymocyte globulin [rATG] or alemtuzumab) followed by belatacept were compared with patients treated with rATG induction followed by tacrolimus [59]. In all patients, glucocorticoids were withdrawn early. The AR incidence was higher in patients treated with belatacept, but the allograft and patient survival were similar [59]. In a third study (described above), alemtuzumab induction with belatacept in KTRs resulted in a high rate of serious adverse events and the study was halted prematurely [47]. T-cell-depleting induction therapy has also been tested in KTRs treated with belatacept in combination with mTOR inhibitors (sirolimus or everolimus). The AR rate in patients treated with this combination of drugs is low, and a significant increase in Tregs is seen [60-63].

Possible explanations for a lower rate of acute rejection after T-cell-depleting induction therapy compared with basiliximab induction therapy were (1) after T-cell-depletion therapy an increased repopulation of Tregs is seen, and (2) repopulated memory T cells in rATG-treated KTRs showed impaired cytokine responsiveness compared with those of basiliximab-treated KTRs [57, 64].

To conclude, although the studies that compared belatacept therapy with tacrolimus therapy have their limitations (limited number of patients or indirect comparison), belatacept is associated with an increased risk of aTCMR. 


\subsection{Clinical Outcomes After Conversion to Belatacept in Kidney Transplant Recipients}

Although the use of belatacept is associated with an increased risk of aTCMR, it has been shown to be a good alternative in KTRs with a contraindication to CNIs. Multiple studies have reported successful conversion to belatacept in KTRs with CNI-induced nephrotoxicity, impaired allograft function, delayed graft function, CNI-mediated thrombotic microangiopathy, or atypical hemolytic uremic syndrome [65-82]. Furthermore, KTRs with poorly controlled diabetes mellitus while receiving CNI therapy may benefit from belatacept $[83,84]$. In addition, since belatacept must be administered intravenously, it has the potential advantage of providing better compliance, for instance in adolescent KTRs [85].

Several approaches for conversion to belatacept have been evaluated, such as early or late conversion [77, 86-89], belatacept combined with a short period of tacrolimus therapy [48], and non-invasive screening for AR after conversion to belatacept to detect AR at an early stage [90]. In a phase II, prospective, randomized trial, KTRs with a stable kidney function were randomized, 6-36 months after transplantation, to maintenance therapy with either belatacept $(n=84)$ or CNIs $(n=89)$ [88]. Three years after randomization, kidney function was better in the belatacept group [89]. The rate of acute rejection was higher in the belatacept group (8.4\%) compared with the CNI-treated patients (3.6\%), but this difference was not statistically significant $(p=0.2)$ [89]. In retrospective studies, a beneficial effect on kidney allograft function was seen in patients with early conversion to belatacept (within 3 months post-transplantation) and patients with low-grade proteinuria [77, 86, 87]. The combination of belatacept with 9 months of tacrolimus reduced the risk of aTCMR in a retrospective, single-center study (the 1-year aTCMR rate of belatacept therapy, tacrolimus therapy, and belatacept plus 9 months of tacrolimus was $50 \%, 20.5 \%$, and $16 \%$, respectively), without an increased incidence of infections [48]. Malvezzi et al. also examined a strategy to safely convert KTRs to belatacept [90]. After the start of belatacept, the dose of tacrolimus was gradually reduced and withdrawn after 2 months. Serial measurements (at 1-, 3-, 6-, and 12-month time points) of urine chemokine (C-X-C motif) ligand 9 (CXCL9) were used to screen for AR non-invasively. In this study, 35 KTRs with a contraindication for CNIs were converted to belatacept after a median of 3.3 years (interquartile range 1.3-7.2) after transplantation [90]. Only one patient had a biopsy-proven AR that responded well to glucocorticoid pulse therapy [90]. The urinary CXCL9 concentration was elevated during AR. In addition to CXCL9, other potential minimally invasive biomarkers in the urine and blood of KTRs, such as cell-free
DNA and extracellular vesicles, may assist clinicians to identify AR at an early stage [91, 92].

Currently, two studies are actively recruiting KTRs for conversion to belatacept; one study will investigate the effect of conversion to belatacept on proteinuria (ClinicalTrials.gov identifier NCT02327403), while the other study will examine the outcomes of conversion to belatacept 3 months after transplantation (ClinicalTrials.gov identifier NCT02213068).

\subsection{Belatacept Therapy in Sensitized Kidney Transplant Recipients}

Initially, most studies that investigated the effectiveness of belatacept included only immunological low-risk KTRs [37, 42, 46]. However, because belatacept therapy is associated with a reduced incidence of de novo DSA production, a growing number of studies on the application of belatacept (de novo and conversion) in sensitized KTRs are available $[18,19]$.

In the BELACOR study, 49 KTRs with preformed DSAs (maximal mean fluorescence intensity between 500 and 3000 ) were treated with induction therapy of rATG followed by de novo belatacept maintenance therapy plus MPA and glucocorticoids [93]. The outcomes were compared with a retrospective control group of patients treated with CNIs. After 1 year of follow-up, no patients in the belatacept group experienced antibody-mediated rejection, while aTCMR occurred significantly more often in the belatacept-treated patients. Complete disappearance of class II DSAs was seen significantly more often in belatacept-treated patients [93].

In a retrospective study, the efficacy of belatacept in reducing anti-HLA antibodies in highly sensitized kidney transplant (current panel reactive antibodies $\geq 98-100 \%$ ) was investigated [94]. Sixty highly sensitized KTRs were treated with belatacept de novo, glucocorticoids, MPA, and low-dose tacrolimus (targeted to predose concentrations $5-8 \mathrm{ng} / \mathrm{mL}$ in the first 6 months, $3-5 \mathrm{ng} / \mathrm{mL}$ in months $6-9$, followed by tapering and discontinuation at months 9-11 post-transplantation). The control group existed of 44 highly sensitized KTRs treated with the current standard-of-care therapy (tacrolimus, MPA, and glucocorticoids). In the KTRs treated with belatacept, a decrease in the breadth and strength of HLA class I antibodies and current panel reactive antibodies was observed compared with the control group [94].

In another retrospective, single-center study, 29 DSApositive KTRs with a contraindication for CNI therapy were converted to belatacept after a median of 444 days [95]. The control group consisted of 44 non-immunized belatacepttreated KTRs. After a median follow-up of 308 days, one belatacept-treated patient experienced AR and two rejections were diagnosed in the CNI-treated patients. The eGFR 
improved from 32 to $41 \mathrm{~mL} / \mathrm{min} / 1.73 \mathrm{~m}^{2}$ after conversion to belatacept [95]. In a smaller retrospective study, similar results were reported in six immunized KTRs (panel reactive antigen $>80 \%$, or positive flow cytometry crossmatch) who were converted from tacrolimus to belatacept (median 4 months after transplantation) [96].

\subsection{Biomarkers Predicting Belatacept-Resistant Rejection}

Because of the increased risk of aTCMR, belatacept may not be the game changer it was hoped to be [20]. Possibly, the drug should be reserved for KTRs with a low risk of belatacept-resistant AR. Quantification of an individual KTR's risk of AR prior to transplantation is essential to identify those who might benefit from belatacept-based immunosuppressive therapy. Clinical tests to reliably predict the risk of belatacept-resistant AR are not yet available. The risk of AR is currently estimated with pretransplant assessment of DSAs, and HLA mismatch; however, alloreactive memory T-cell responses are not measured with these assays. The presence of alloreactive $\mathrm{T}$ cells pretransplantation can lead to rapid recognition of alloantigens after transplantation, and early AR $[97,98]$. These alloreactive $T$ cells can be measured with pretransplantation functional assays (e.g. measurement donor-reactive immune cells with enzyme-linked immunosorbent spot [ELISpot]) [97, 99].

Several studies have been performed to elucidate the pathogenesis of AR after belatacept therapy. An immunomic analysis of biopsies with AR of KTRs treated with tacrolimus or belatacept showed no difference in the intragraft gene expression and immunohistochemistry of markers that are involved in AR [100]. This implies a final common pathway of AR that is independent of the immunosuppressive regimen.

Apart from the effect of belatacept on Tregs [51-55], other $\mathrm{T}$ cells have been associated with belatacept-resistant $\mathrm{AR}$, such as highly cytotoxic $\mathrm{CD} 28^{-}$memory $\mathrm{T}$ cells, $\mathrm{CD} 4^{+}$ $\mathrm{CD} 28^{+}$effector memory $\mathrm{T}$ cells, $\mathrm{CD} 4^{+} \mathrm{CD} 57^{+}$Programmed Death- $1^{-} \mathrm{T}$ cells, and T helper (Th) 17 memory cells [46, 98, 101-105]. However, conflicting data have been reported regarding the possibility of predicting belatacept-resistant AR by measuring some of these T-cell subsets [46, 98, 101-105], and currently none are clinically reliable for AR risk.

Another reason that may contribute to the increased incidence of AR is that belatacept therapy does not inhibit the T-cell activation pathway downstream of the TCR, in contrast to tacrolimus therapy [106]. In a study of 20 belatacepttreated KTRs, no inhibition of the phosphorylation of three important signaling molecules (p38MAPK, extracellular signal-regulated kinases [ERK] 1 and 2, and AKT8 virus oncogene cellular homolog [Akt]) was noted after treatment with belatacept [106]. Furthermore, the phosphorylation of ERK was increased in belatacept-treated patients on days 4 and 90 in patients with an AR compared with patients without an AR [106].

Prediction of AR was not possible with a targeted proteomic analysis of pre-rejection serum samples of KTRs treated with belatacept [107]. In an assay with 92 inflammation-related proteins, no difference was seen in the proteomic profile between the pre-rejection samples and samples of patients without AR [107].

To conclude, there are several explanations for the increased risk of AR associated with belatacept therapy. At present, no specific tests (besides pretransplant screening for degree of sensitization) are available that can predict the risk for belatacept-resistant AR.

\section{Alternative Approaches of Costimulation Blockade}

\subsection{CD28 Antibodies}

Selective targeting of the CD28 antigen on T cells might be a superior immunosuppressive therapy compared with belatacept since this blockade leaves the inhibitory signal of CTLA-4 intact and may preserve Treg function (Fig. 1) [108, 109]; however, blockade of CD28 has been challenging. Most anti-CD28 antibodies bind to an epitope lying in the basolateral C''D domain of CD28. Crosslinking of this epitope with an anti-CD28 antibody results in receptor clusterization, which leads to activation of the CD28 receptor instead of inhibition. In 2006, a CD28 humanized antibody (TGN1412) was tested in a phase I study (Fig. 2) [110]. This antibody was developed to cause activation and proliferation of Tregs independent of signals received from the TCR. In studies in cynomolgus macaques, TGN1412 revealed no toxic effects; however, in humans, infusion of TGN1412 led to life-threatening massive cytokine release in six healthy volunteers, and all of them had to be transferred to the intensive care unit [110]. CD4 ${ }^{+}$effector memory $\mathrm{T}$ cells appeared to be responsible for the massive cytokine release [111]. The reason that preclinical testing failed to predict this dramatic adverse effect was that $\mathrm{CD}^{+}{ }^{+}$effector memory $\mathrm{T}$ cells of cynomolgus macaques do not express CD28, therefore these cells cannot be stimulated with TGN1412 [111].

Currently, two monovalent antibodies with only antagonistic action to CD28 are in clinical development-FR104 and lulizumab-pegol (Fig. 2) [112, 113]. In non-human primates transplanted with a kidney allograft, FR104 in combination with rapamycin, a low dose of tacrolimus, or 1 month of low-dose tacrolimus, induced long-term allograft survival $[114,115]$. Lulizumab-pegol was tested in non-human primates and showed inhibition of T-cell-dependent antibody 
responses and cytokine production [116]. In humans, both drugs have been evaluated in phase I clinical studies and were safe and well tolerated (Fig. 2) [113]. At present, a prospective multicenter study has been started to investigate the efficacy of lulizumab in combination with rATG, glucocorticoids, belatacept, tocilizumab, and everolimus in KTRs (ClinicalTrials.gov identifier NCT04066114).

\subsection{CD2/SLAM Family Antibodies}

An antibody that interferes with the CD2/SLAM family is alefacept (Fig. 1). This is a fusion protein of lymphocyte function-associated antigen (LFA)-3 and the Fc part of IgG1 [117]. LFA-3 is expressed on APCs and is the ligand of CD2 on T cells. CD2 is expressed on all T cells, but memory $\mathrm{T}$ cells express the highest levels [118]. Alefacept binds to $\mathrm{CD} 2$ on T cells and blocks the interaction between CD2 and LFA-3. It was approved by the FDA in 2003 for the treatment of psoriasis, and administration of alefacept leads to the depletion of memory T cells (Fig. 2) [117]. In a phase II, randomized, controlled, double-blind, multicenter study, maintenance treatment with alefacept was compared with placebo in KTRs [119]. Both patient groups were also treated with tacrolimus, MPA, and glucocorticoids. There was no significant difference in the rate of biopsy-proven AR (alefacept $11 \%$ vs. placebo $7 \%$; $p=0.3$ ). Furthermore, malignancy occurred more often in patients treated with alefacept (5.7\%) compared with placebo $(0.9 \% ; p=0.06)$ [119]. In 2011, the manufacturer decided to stop the development of alefacept [120].

\subsection{CD40/CD154 (CD40 Ligand) Antibodies}

The CD40/CD154 pathway is a promising target for immunosuppressive therapy in KTRs. CD40 (TNF receptor superfamily 5 [TNFRSF5]) is constitutively expressed on the surface of APCs, including B cells, macrophages and dendritic cells, and T cells (mainly $\mathrm{CD}^{+}$) [121]. CD154 is the ligand of CD40 and is expressed on activated T cells and subsets of natural killer cells, eosinophils, and activated thrombocytes (Fig. 1) [121]. Ligation of CD40 with CD154 leads to T-cell-dependent B-cell activation and proliferation, germinal center formation, Ig production, and isotype class switching. Furthermore, stimulation of CD40 provides macrophage effector function and promotes CD28-mediated costimulation through upregulation of CD80/CD86 and HLA molecules on APCs [122, 123].

Multiple antibodies that target the CD40/CD154 pathway have been developed and tested in patients with autoimmune diseases, such as systemic lupus erythematosus, rheumatoid arthritis, psoriasis, inflammatory bowel disease, and idiopathic thrombocytic purpura [124]. Several CD154 monoclonal antibodies (e.g. hu5C8, IDEC-131, ABI793, and
H106) were tested in non-human primates and showed prolonged kidney allograft survival [33, 125-128]. However, in humans, administration of anti-CD154 antibodies led to an unanticipated, higher incidence of thrombotic complications, possibly because of activation of the coagulation cascade through CD154 activation on thrombocytes [129]. Therefore, the clinical development of anti-CD154 antibodies was terminated. Since CD40 is not expressed on thrombocytes, antagonistic anti-CD40 antibodies might not evoke thrombotic events. At present, many antagonistic anti-CD40 antibodies (e.g. ASKP1240, CFZ533, HCD122, Chi220, 3A8, 2C10R1, 2C10R4, BI-655064, FFP104, ch5D12) are under investigation $[124,130]$. Two of these anti-CD40 antibodies have been tested in KTRs, namely CFZ533 (iscalimab) and ASKP1240 (bleselumab).

Bleselumab is a fully humanized, non-depleting, antiCD40 IgG4 antibody. In non-human primates, bleselumab prolonged kidney allograft survival [131]. In a phase Ib study in KTRs, bleselumab was well tolerated and no thrombotic events occurred [132]. A more extensive (phase II) trial examined the efficacy and safety of bleselumab in KTRs (ClinicalTrials.gov identifier NCT01780844) (Fig. 2). Preliminary data presented at a conference showed that the incidence of AR 3 years of therapy was 13\% in KTRs treated with standard therapy (tacrolimus), $11 \%$ in patients treated with bleselumab with low-dose tacrolimus ( $p=1.00$ vs. standard therapy), and $41 \%$ in patients treated with bleselumab ( $p=0.02$ vs. standard therapy) [133]. Furthermore, an increased incidence of cytomegalovirus and BK virus infections was seen in patients treated with bleselumab [132, 133].

Iscalimab is a non-B-cell-depleting anti-CD40 antibody that induced prolonged survival and function of kidney allografts in cynomolgus monkeys [134]. Furthermore, iscalimab led to complete absence of splenic germinal center formation, and formation of de novo DSA [134]. It is currently being tested in 325 KTRs in a phase II trial (ClinicalTrials.gov identifier NCT02217410) comparing standard-of-care therapy (tacrolimus, MPA, and glucocorticoids) with subcutaneous iscalimab every 2 weeks in combination with MPA and glucocorticoids (Fig. 2). Data from a proof-of-concept trial performed in 2016-2017 demonstrated comparable efficacy on the composite endpoint of AR, graft loss, or death $(21.2 \%$ vs. $22.2 \%)$, better kidney function ( 55.8 vs. $45.5 \mathrm{~mL} / \mathrm{min} / 1.73 \mathrm{~m}^{2}$ ), and a reduced incidence of post-transplant diabetes mellitus (14.7 vs. $38.9 \%$ ) in patients treated with iscalimab compared with tacrolimus after 6 months of treatment [135].

\section{Future Directions}

Modulation of the costimulation pathway with biologicals remains a promising strategy for the prevention of AR because it is more specific than traditional pharmacologic 
immunosuppression and appears to have the advantage of having only limited non-immune toxicity. To date, belatacept is the only costimulation blockade therapy approved for the prevention of rejection. Although belatacept has been shown to be a promising therapy in subgroups of patients, its widespread use has been limited because of (1) the increased risk of aTCMR compared with tacrolimus; (2) concerns regarding its safety (increased risk of post-transplant lymphoproliferative disorder); and (3) logistical aspects, including the need for regular infusions and its temporary unavailability due to production shortages.

The use of belatacept could be expanded in the future, when it is possible to reliably identify patients who are at a low risk for belatacept-resistant AR (Fig. 3). Belatacept-based therapy may be administered to these low-risk patients, while the standard of care (tacrolimus-based therapy) should be offered to KTRs with a high risk for belatacept-resistant AR (Fig. 3). Belatacept may also be an attractive alternative for patients with contraindications for CNIs (Fig. 3).

Another strategy to expand the use of belatacept is to combine belatacept with tacrolimus or other immunosuppressive therapies (Fig. 3). The risk of belatacept-resistant $\mathrm{AR}$ is reduced when it is used in combination with a short period, or low-dose, of tacrolimus [48, 90]. Belatacept therapy influences the immunosuppressive function of Tregs
[51-55]; therefore, the combination of belatacept with therapies that preserve Treg functionality, such as mTOR inhibitors, T-cell-depletion therapy, anti-CD40 antibodies, and adoptive therapy with Tregs could possibly lead to a more precise control of alloimmunity (Fig. 3) [56]. The combination of CTLA4/Ig and blockade of CD40/CD154 has not yet been tested in humans; however, in several animal transplant models, this combination produced long-term allograft survival [136-140].

$\mathrm{CD} 28^{-}$memory $\mathrm{T}$ cells are insensitive to belatacept therapy; therefore, belatacept should be avoided in KTRs with a high number of these cells, or should be combined with drugs that effectively control $\mathrm{CD} 28^{-}$memory T-cell immunity (Fig. 3). Mesenchymal stem cell therapy has immunomodulatory properties and, in vitro, these cells are shown to inhibit CD28- memory T cells [141, 142]. The combination of alemtuzumab induction followed by infusion with mesenchymal stem cells, belatacept, and sirolimus is currently being tested (ClinicalTrials.gov identifier NCT03504241).

More intensive monitoring of KTRs after conversion to belatacept might lead to better prevention or earlier recognition of AR. Belatacept dosing is administered at fixed intervals and is based on the body weight of the patient. According to the manufacturer of belatacept, it is not advisable to perform therapeutic drug monitoring of belatacept [143].

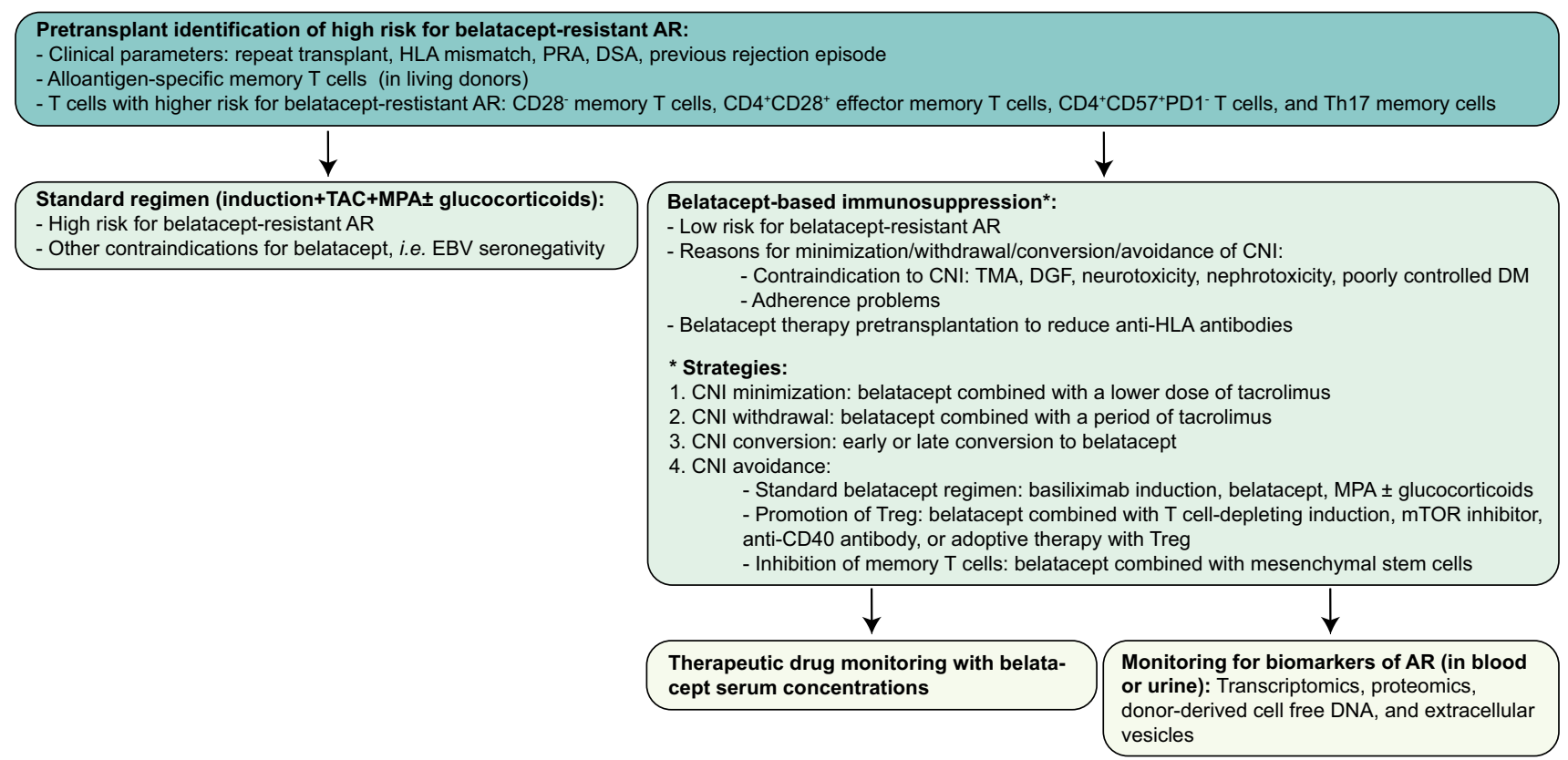

Fig. 3 Future directions for belatacept treatment in kidney transplant recipients. A more tailored approach in the selection, treatment strategy, and postconversion monitoring might be a way to expand the use of belatacept in kidney transplant recipients. $A R$ acute kidney transplant rejection, $C N I$ calcineurin inhibitors, $D G F$ delayed graft function, $D M$ diabetes mellitus, DSA donor-specific anti-HLA antibod- ies, $E B V$ Epstein-Barr virus, $H L A$ human leucocyte antigen, $M P A$ mycophenolic acid, mTOR mammalian target of rapamycin, $P D-1$ programmed death-1, $P R A$ panel reactive antigens, TAC tacrolimus, Th17 $\mathrm{T}$ helper 17, TMA thrombotic microangiopathy, Treg regulatory $\mathrm{T}$ cells 
However, in the BENEFIT studies, a more intensive regimen was associated with an increased incidence of malignancies and infections, without an increase in efficacy [37, 38]. An automated assay to determine belatacept serum concentrations was recently developed [144]. The authors found reduced peak concentrations of belatacept in patients with a lower bodyweight [144]; however, whether this reduced exposure to belatacept leads to an increased risk of AR is unknown, but is certainly a reason for further investigation (Fig. 3).

Belatacept is currently administered every 4 weeks in the maintenance phase. In a 10-year follow-up study, the belatacept 4-weekly regimen was compared with administration of belatacept every 8 weeks [145]. After 10 years, kidney function and the risk of allograft loss or death was similar between the two groups; however, the risk of AR was higher in patients who received belatacept every 8 weeks [2]. With further investigation, such as the above-mentioned measurement of belatacept serum concentrations, the 8-weekly dosing regimen could offer logistical advantages in subgroups of KTRs in the future.

Early recognition and treatment of AR leads to less allograft damage; therefore, minimally invasive screening for (preclinical) AR in KTRs could lead to better allograft survival (Fig. 3). Potential biomarkers for minimally invasive screening of AR in blood or urine are now entering the clinic [91, 107, 146]. Applying these minimally invasive screening tools to belatacept-treated patients could be a way to expand the use of belatacept.

To conclude, targeting the costimulation pathway is a complex but exciting task. Belatacept is a promising immunosuppressive therapy for KTRs, but a more tailored approach in the selection of patients, treatment protocol, and post-transplant monitoring is necessary to expand the use of belatacept.

Author Contributions MvdZ participated in the writing of the article, and DAH, MWFvdH, and CCB participated in the critical revision of the manuscript.

Funding No sources of funding were used in the preparation of this article.

\section{Compliance with Ethical Standards}

Conflict of interest Dennis A. Hesselink has received grant support, and lecture and consulting fees from Astellas Pharma and Chiesi Pharmaceuticals, as well as lecture fees from Hikma Pharma and grant support from Bristol Myers-Squibb. Martijn W.F van den Hoogen has received grant support from Novartis and Shire, and lecture fees from Astellas Pharma, Chiesi Pharmaceuticals, MSD, Sanofi/Genzyme, Shire and Vifor Pharma. Marieke van der Zwan and Carla C. Baan declare no conflicts of interest.

Open Access This article is distributed under the terms of the Creative Commons Attribution-NonCommercial 4.0 International License (http://creativecommons.org/licenses/by-nc/4.0/), which permits any noncommercial use, distribution, and reproduction in any medium, provided you give appropriate credit to the original author(s) and the source, provide a link to the Creative Commons license, and indicate if changes were made.

\section{References}

1. Kasiske BL, Zeier MG, Chapman JR, Craig JC, Ekberg H, Garvey CA, et al. KDIGO clinical practice guideline for the care of kidney transplant recipients: a summary. Kidney Int. 2010;77(4):299-311.

2. Brunet M, van Gelder T, Asberg A, Haufroid V, Hesselink DA, Langman L, et al. Therapeutic drug monitoring of tacrolimuspersonalized therapy: second consensus report. Ther Drug Monit. 2019;41(3):261-307.

3. van Gelder T, Hesselink DA. Mycophenolate revisited. Transpl Int. 2015;28(5):508-15.

4. van der Zwan M, Baan CC, van Gelder T, Hesselink DA. Review of the clinical pharmacokinetics and pharmacodynamics of alemtuzumab and its use in kidney transplantation. Clin Pharmacokinet. 2018;57(2):191-207.

5. Claes K, Meier-Kriesche HU, Schold JD, Vanrenterghem Y, Halloran PF, Ekberg H. Effect of different immunosuppressive regimens on the evolution of distinct metabolic parameters: evidence from the symphony study. Nephrol Dial Transpl. 2012;27(2):850-7.

6. Nankivell BJ, Borrows RJ, Fung CL, O'Connell PJ, Allen RD, Chapman JR. The natural history of chronic allograft nephropathy. N Engl J Med. 2003;349(24):2326-33.

7. Ekberg H, Tedesco-Silva H, Demirbas A, Vitko S, Nashan B, Gurkan A, et al. Reduced exposure to calcineurin inhibitors in renal transplantation. N Engl J Med. 2007;357(25):2562-75.

8. Neuberger JM, Bechstein WO, Kuypers DR, Burra P, Citterio F, De Geest S, et al. Practical Recommendations for long-term management of modifiable risks in kidney and liver transplant recipients: a guidance report and clinical checklist by the consensus on managing modifiable risk in transplantation (COMMIT) group. Transplantation. 2017;101(4S Suppl 2):S1-56.

9. Tedesco-Silva H, Kho MM, Hartmann A, Vitko S, Russ G, Rostaing $\mathrm{L}$, et al. Sotrastaurin in calcineurin inhibitor-free regimen using everolimus in de novo kidney transplant recipients. Am J Transpl. 2013;13(7):1757-68.

10. Baan CC, Kannegieter NM, Felipe CR, Tedesco Silva H Jr. Targeting JAK/STAT signaling to prevent rejection after kidney transplantation: a reappraisal. Transplantation. 2016;100(9):1833-9.

11. Vincenti F, Silva HT, Busque S, O'Connell PJ, Russ G, Budde K, et al. Evaluation of the effect of tofacitinib exposure on outcomes in kidney transplant patients. Am J Transpl. 2015;15(6):1644-53.

12. Bouamar R, Shuker N, Osinga JAJ, Clahsen-van Groningen $\mathrm{MC}$, Damman J, Baan CC, et al. Conversion from tacrolimus to everolimus with complete and early glucocorticoid withdrawal after kidney transplantation: a randomised trial. Neth J Med. 2018;76(1):14-26.

13. Shipkova M, Hesselink DA, Holt DW, Billaud EM, van Gelder T, Kunicki PK, et al. Therapeutic drug monitoring of everolimus: a consensus report. Ther Drug Monit. 2016;38(2):143-69.

14. Pascual J, Berger SP, Witzke O, Tedesco H, Mulgaonkar S, Qazi $\mathrm{Y}$, et al. Everolimus with reduced calcineurin inhibitor exposure in renal transplantation. J Am Soc Nephrol. 2018;29(7):1979-91.

15. Karpe KM, Talaulikar GS, Walters GD. Calcineurin inhibitor withdrawal or tapering for kidney transplant recipients. Cochrane Database Syst Rev. 2017;7:CD006750. 
16. Larsen CP, Pearson TC, Adams AB, Tso P, Shirasugi N, Strobert $\mathrm{E}$, et al. Rational development of LEA29Y (belatacept), a highaffinity variant of CTLA4-Ig with potent immunosuppressive properties. Am J Transpl. 2005;5(3):443-53.

17. Archdeacon P, Dixon C, Belen O, Albrecht R, Meyer J. Summary of the US FDA approval of belatacept. Am J Transpl. 2012;12(3):554-62.

18. Durrbach A, Pestana JM, Florman S, Del Carmen RM, Rostaing L, Kuypers D, et al. Long-term outcomes in belatacept- versus cyclosporine-treated recipients of extended criteria donor kidneys: final results from BENEFIT-EXT, a Phase III Randomized Study. Am J Transpl. 2016;16(11):3192-201.

19. Vincenti F, Rostaing L, Grinyo J, Rice K, Steinberg S, Gaite L, et al. Belatacept and long-term outcomes in kidney transplantation. N Engl J Med. 2016;374(4):333-43.

20. Van Gelder T, Hesselink DA. Belatacept: a game changer? Transplantation. 2016;100(7):1390-2.

21. Sharpe AH. Mechanisms of costimulation. Immunol Rev. 2009;229(1):5-11.

22. June CH, Ledbetter JA, Gillespie MM, Lindsten T, Thompson CB. T-cell proliferation involving the CD28 pathway is associated with cyclosporine-resistant interleukin 2 gene expression. Mol Cell Biol. 1987;7(12):4472-81.

23. Mueller DL, Jenkins MK, Schwartz RH. Clonal expansion versus functional clonal inactivation: a costimulatory signalling pathway determines the outcome of $\mathrm{T}$ cell antigen receptor occupancy. Annu Rev Immunol. 1989;7:445-80.

24. Nakayama T, Yamashita M. The TCR-mediated signaling pathways that control the direction of helper $\mathrm{T}$ cell differentiation. Semin Immunol. 2010;22(5):303-9.

25. O'Shea JJ, Paul WE. Mechanisms underlying lineage commitment and plasticity of helper CD4 $+\mathrm{T}$ cells. Science. 2010;327(5969):1098-102.

26. Linsley PS, Greene JL, Tan P, Bradshaw J, Ledbetter JA, Anasetti $\mathrm{C}$, et al. Coexpression and functional cooperation of CTLA-4 and CD28 on activated T lymphocytes. J Exp Med. 1992;176(6):1595-604.

27. Weng NP, Akbar AN, Goronzy J. CD28(-) T cells: their role in the age-associated decline of immune function. Trends Immunol. 2009;30(7):306-12.

28. Betjes MG, Huisman M, Weimar W, Litjens NH. Expansion of cytolytic CD4 + CD28- T cells in end-stage renal disease. Kidney Int. 2008;74(6):760-7.

29. Pawelec G, Derhovanessian E. Role of CMV in immune senescence. Virus Res. 2011;157(2):175-9.

30. Sprent J, Surh CD. T cell memory. Annu Rev Immunol. 2002;20:551-79.

31. Linsley PS, Brady W, Urnes M, Grosmaire LS, Damle NK, Ledbetter JA. CTLA-4 is a second receptor for the B cell activation antigen B7. J Exp Med. 1991;174(3):561-9.

32. Kremer JM, Westhovens R, Leon M, Di Giorgio E, Alten R, Steinfeld $\mathrm{S}$, et al. Treatment of rheumatoid arthritis by selective inhibition of T-cell activation with fusion protein CTLA4Ig. N Engl J Med. 2003;349(20):1907-15.

33. Kirk AD, Harlan DM, Armstrong NN, Davis TA, Dong Y, Gray GS, et al. CTLA4-Ig and anti-CD40 ligand prevent renal allograft rejection in primates. Proc Natl Acad Sci USA. 1997;94(16):8789-94.

34. Levisetti MG, Padrid PA, Szot GL, Mittal N, Meehan SM, Wardrip CL, et al. Immunosuppressive effects of human CTLA4Ig in a non-human primate model of allogeneic pancreatic islet transplantation. J Immunol. 1997;159(11):5187-91.

35. Badell IR, Karadkhele GM, Vasanth P, Farris AB 3rd, Robertson JM, Larsen CP. Abatacept as rescue immunosuppression after calcineurin inhibitor treatment failure in renal transplantation. Am J Transpl. 2019;19(8):2342-9.
36. Gabardi S, van Gelder T. Causes and consequences of the worldwide belatacept shortage. Transplantation. 2017;101(7):1520-1.

37. Vincenti F, Charpentier B, Vanrenterghem Y, Rostaing L, Bresnahan B, Darji P, et al. A phase III study of belatacept-based immunosuppression regimens versus cyclosporine in renal transplant recipients (BENEFIT study). Am J Transpl. 2010;10(3):535-46.

38. Durrbach A, Pestana JM, Pearson T, Vincenti F, Garcia VD, Campistol J, et al. A phase III study of belatacept versus cyclosporine in kidney transplants from extended criteria donors (BENEFIT-EXT study). Am J Transpl. 2010;10(3):547-57.

39. van den Hoogen MW, Pipeleers L. Three-year outcomes of belatacept studies; reason to be optimistic? Am J Transpl. 2012;12(8):2259 (discussion 2260).

40. Klintmalm GB, Feng S, Lake JR, Vargas HE, Wekerle T, Agnes $\mathrm{S}$, et al. Belatacept-based immunosuppression in de novo liver transplant recipients: 1-year experience from a phase II randomized study. Am J Transplant. 2014;14(8):1817-27.

41. Knechtle SJ, Adams AB. Belatacept: is there BENEFIT for liver transplantation too? Am J Transpl. 2014;14(8):1717-8.

42. Masson P, Henderson L, Chapman JR, Craig JC, Webster AC. Belatacept for kidney transplant recipients. Cochrane Database Syst Rev. 2014;11:CD010699.

43. Vitalone MJ, Ganguly B, Hsieh S, Latek R, Kulbokas EJ, Townsend R, et al. Transcriptional profiling of belatacept and calcineurin inhibitor therapy in renal allograft recipients. Am J Transpl. 2014;14(8):1912-21.

44. Furuzawa-Carballeda J, Uribe-Uribe NO, Arreola-Guerra JM, Reyes-Acevedo R, Vilatoba M, Lopez-Toledo A, et al. Tissue talks: immunophenotype of cells infiltrating the graft explains histological findings and the benefits of belatacept at 10 years. Clin Exp Immunol. 2019;197(2):250-61.

45. Webster AC, Woodroffe RC, Taylor RS, Chapman JR, Craig JC. Tacrolimus versus ciclosporin as primary immunosuppression for kidney transplant recipients: meta-analysis and meta-regression of randomised trial data. BMJ. 2005;331(7520):810.

46. de Graav GN, Baan CC, Clahsen-van Groningen MC, Kraaijeveld $\mathrm{R}$, Dieterich M, Verschoor W, et al. A randomized controlled clinical trial comparing belatacept with tacrolimus after de novo kidney transplantation. Transplantation. 2017;101(10):2571-81.

47. Newell KA, Mehta AK, Larsen CP, Stock PG, Farris AB, Mehta $\mathrm{SG}$, et al. lessons learned: early termination of a randomized trial of calcineurin inhibitor and corticosteroid avoidance using belatacept. Am J Transpl. 2017;17(10):2712-9.

48. Adams AB, Goldstein J, Garrett C, Zhang R, Patzer RE, Newell $\mathrm{KA}$, et al. Belatacept combined with transient calcineurin inhibitor therapy prevents rejection and promotes improved long-term renal allograft function. Am J Transpl. 2017;17(11):2922-36.

49. Cohen JB, Eddinger KC, Forde KA, Abt PL, Sawinski D. Belatacept compared with tacrolimus for kidney transplantation: a propensity score matched cohort study. Transplantation. 2017;101(10):2582-9.

50. Muduma G, Hart WM, Patel S, Odeyemi AO. Indirect treatment comparison of belatacept versus tacrolimus from a systematic review of immunosuppressive therapies for kidney transplant patients. Curr Med Res Opin. 2016;32(6):1065-72.

51. Read S, Malmstrom V, Powrie F. Cytotoxic T lymphocyte-associated antigen 4 plays an essential role in the function of CD25(+) $\mathrm{CD} 4(+)$ regulatory cells that control intestinal inflammation. $\mathrm{J}$ Exp Med. 2000;192(2):295-302.

52. Takahashi T, Tagami T, Yamazaki S, Uede T, Shimizu J, Sakaguchi N, et al. Immunologic self-tolerance maintained by $\mathrm{CD} 25(+) \mathrm{CD} 4(+)$ regulatory $\mathrm{T}$ cells constitutively expressing cytotoxic $\mathrm{T}$ lymphocyte-associated antigen 4 . J Exp Med. 2000;192(2):303-10. 
53. Wing K, Onishi Y, Prieto-Martin P, Yamaguchi T, Miyara M, Fehervari Z, et al. CTLA-4 control over Foxp3 + regulatory T cell function. Science. 2008;322(5899):271-5.

54. Alvarez Salazar EK, Cortes-Hernandez A, Aleman-Muench GR, Alberu J, Rodriguez-Aguilera JR, Recillas-Targa F, et al. Methylation of FOXP3 TSDR underlies the impaired suppressive function of tregs from long-term belatacept-treated kidney transplant patients. Front Immunol. 2017;8:219.

55. Riella LV, Liu T, Yang J, Chock S, Shimizu T, Mfarrej B, et al. Deleterious effect of CTLA4-Ig on a Treg-dependent transplant model. Am J Transpl. 2012;12(4):846-55.

56. Zwang NA, Leventhal JR. Cell therapy in kidney transplantation: focus on regulatory T cells. J Am Soc Nephrol. 2017;28(7):1960-72.

57. Bouvy AP, Klepper M, Kho MM, Boer K, Betjes MG, Weimar $\mathrm{W}$, et al. The impact of induction therapy on the homeostasis and function of regulatory $\mathrm{T}$ cells in kidney transplant patients. Nephrol Dial Transpl. 2014;29(8):1587-97.

58. Sparkes T, Ravichandran B, Opara O, Ugarte R, Drachenberg $\mathrm{CB}$, Philosophe B, et al. Alemtuzumab induction and belatacept maintenance in marginal pathology renal allografts. Clin Transpl. 2019;33(6):e13531.

59. Woodle E, Kaufman D, Shields A, et al. The BEST Trial: a prospective randomized multicenter trial of Belatacept-based CNIand corticosteroid-free immunosuppression. https://atcmeeting abstracts.com/abstract/the-best-trial-a-prospective-randomized -multicenter-trial-of-belatacept-based-cni-and-corticosteroidfree-immunosuppression/. Accessed 15 Aug 2019 (abstract).

60. Kirk AD, Guasch A, Xu H, Cheeseman J, Mead SI, Ghali A, et al. Renal transplantation using belatacept without maintenance steroids or calcineurin inhibitors. Am J Transpl. 2014;14(5):1142-51.

61. Ferguson R, Grinyo J, Vincenti F, Kaufman DB, Woodle ES, Marder BA, et al. Immunosuppression with belatacept-based, corticosteroid-avoiding regimens in de novo kidney transplant recipients. Am J Transpl. 2011;11(1):66-76.

62. Bestard O, Cassis L, Cruzado JM, Torras J, Franquesa M, GilVernet $\mathrm{S}$, et al. Costimulatory blockade with mTor inhibition abrogates effector T-cell responses allowing regulatory T-cell survival in renal transplantation. Transpl Int. 2011;24(5):451-60.

63. Wojciechowski D, Chandran S, Yang JYC, Sarwal MM, Vincenti F. Retrospective evaluation of the efficacy and safety of belatacept with thymoglobulin induction and maintenance everolimus: a single-center clinical experience. Clin Transplant. 2017. https ://doi.org/10.1111/ctr.13042.

64. Bouvy AP, Klepper M, Kho MM, Ijzermans JN, Betjes MG, Weimar W, et al. T cells exhibit reduced signal transducer and activator of transcription 5 phosphorylation and upregulated coinhibitory molecule expression after kidney transplantation. Transplantation. 2015;99(9):1995-2003.

65. Ebcioglu Z, Liu C, Shapiro R, Rana M, Salem F, Florman S, et al. Belatacept conversion in an HIV-positive kidney transplant recipient with prolonged delayed graft function. Am J Transpl. 2016;16(11):3278-81.

66. Kumar D, Yakubu I, Cooke RH, Halloran PF, Gupta G. Belatacept rescue for delayed kidney allograft function in a patient with previous combined heart-liver transplant. Am J Transpl. 2018;18(10):2613-4.

67. Wojciechowski D, Chandran S, Vincenti F. Early post-transplant conversion from tacrolimus to belatacept for prolonged delayed graft function improves renal function in kidney transplant recipients. Clin Transplant. 2017. https://doi.org/10.1111/ctr.12930.

68. Ashman N, Chapagain A, Dobbie H, Raftery MJ, Sheaff MT, Yaqoob MM. Belatacept as maintenance immunosuppression for postrenal transplant de novo drug-induced thrombotic microangiopathy. Am J Transpl. 2009;9(2):424-7.
69. Cicora F, Paz M, Mos F, Roberti J. Use of belatacept as alternative immunosuppression in three renal transplant patients with de novo drug-induced thrombotic microangiopathy. Case Rep Med. 2013;2013:260254.

70. Koppula S, Yost SE, Sussman A, Bracamonte ER, Kaplan B. Successful conversion to belatacept after thrombotic microangiopathy in kidney transplant patients. Clin Transpl. 2013;27(4):591-7.

71. Merola J, Yoo PS, Schaub J, Smith JD, Rodriguez-Davalos MI, Tichy E, et al. Belatacept and eculizumab for treatment of calcineurin inhibitor-induced thrombotic microangiopathy after kidney transplantation: case report. Transpl Proc. 2016;48(9):3106-8.

72. Dedhia P, Govil A, Mogilishetty G, Alloway RR, Woodle ES, Abu Jawdeh BG. Eculizumab and belatacept for de novo atypical hemolytic uremic syndrome associated With CFHR3-CFHR1 deletion in a kidney transplant recipient: a case report. Transpl Proc. 2017;49(1):188-92.

73. Midtvedt K, Bitter J, Dorje C, Bjorneklett R, Holdaas H. Belatacept as immunosuppression in patient with recurrence of hemolytic uremic syndrome after renal transplantation. Transplantation. 2009;87(12):1901-3.

74. Tatapudi VS, Lonze BE, Wu M, Montgomery RA. Early conversion from tacrolimus to belatacept in a highly sensitized renal allograft recipient with calcineurin inhibitor-induced de novo post-transplant hemolytic uremic syndrome. Case Rep Nephrol Dial. 2018;8(1):10-9.

75. Gupta S, Rosales I, Wojciechowski D. Pilot analysis of late conversion to belatacept in kidney transplant recipients for biopsy-proven chronic tacrolimus toxicity. J Transpl. 2018;2018:1968029.

76. Snyder HS, Duhart BT, Jr., Krauss AG, Rao V. Belatacept conversion in African American kidney transplant recipients with severe renal dysfunction. SAGE Open Med Case Rep. 2016;4:2050313X16674865.

77. Le Meur Y, Aulagnon F, Bertrand D, Heng AE, Lavaud S, Caillard S, et al. Effect of an early switch to belatacept among calcineurin inhibitor-intolerant graft recipients of kidneys from extended-criteria donors. Am J Transpl. 2016;16(7):2181-6.

78. Bertrand D, Cheddani L, Etienne I, Francois A, Hanoy M, Laurent $\mathrm{C}$, et al. Belatacept rescue therapy in kidney transplant recipients with vascular lesions: a case control study. Am J Transpl. 2017;17(11):2937-44.

79. Belliere J, Guilbeau-Frugier C, Del Bello A, Esposito L, Capuani $\mathrm{C}$, Cardeau-Desangles I, et al. Beneficial effect of conversion to belatacept in kidney-transplant patients with a low glomerularfiltration rate. Case Rep Transpl. 2014;2014:190516.

80. Abdelwahab Elhamahmi D, Heilman RL, Smith B, Huskey J, Khamash H, Kaplan B. Early conversion to belatacept in kidney transplant recipients with low glomerular filtration rate. Transplantation. 2018;102(3):478-83.

81. Nair V, Liriano-Ward L, Kent R, Huprikar S, Rana M, Florman SS, et al. Early conversion to belatacept after renal transplantation. Clin Transplant. 2017. https://doi.org/10.1111/ctr.12951.

82. Brakemeier S, Kannenkeril D, Durr M, Braun T, Bachmann F, Schmidt D, et al. Experience with belatacept rescue therapy in kidney transplant recipients. Transpl Int. 2016;29(11):1184-95.

83. de Graav GN, van der Zwan M, Baan CC, Janssen J, Hesselink DA. Improved glucose tolerance in a kidney transplant recipient with type 2 diabetes mellitus after switching from tacrolimus to belatacept: a case report and review of potential mechanisms. Transpl Direct. 2018;4(3):e350.

84. Vanrenterghem Y, Bresnahan B, Campistol J, Durrbach A, Grinyo J, Neumayer HH, et al. Belatacept-based regimens are associated with improved cardiovascular and metabolic risk factors compared with cyclosporine in kidney transplant recipients 
(BENEFIT and BENEFIT-EXT studies). Transplantation. 2011;91(9):976-83.

85. Lerch C, Kanzelmeyer NK, Ahlenstiel-Grunow T, Froede K, Kreuzer M, Drube J, et al. Belatacept after kidney transplantation in adolescents: a retrospective study. Transpl Int. 2017;30(5):494-501.

86. Durr M, Lachmann N, Zukunft B, Schmidt D, Budde K, Brakemeier S. Late conversion to belatacept after kidney transplantation: outcome and prognostic factors. Transpl Proc. 2017;49(8):1747-1756.e1.

87. Darres A, Ulloa C, Brakemeier S, Garrouste C, Bestard O, Del Bello A, et al. Conversion to belatacept in maintenance kidney transplant patients: a retrospective Multicenter European Study. Transplantation. 2018;102(9):1545-52.

88. Rostaing L, Massari P, Garcia VD, Mancilla-Urrea E, Nainan $\mathrm{G}$, del Carmen RM, et al. Switching from calcineurin inhibitorbased regimens to a belatacept-based regimen in renal transplant recipients: a randomized phase II study. Clin J Am Soc Nephrol. 2011;6(2):430-9.

89. Grinyo JM, Del Carmen RM, Alberu J, Steinberg SM, Manfro RC, Nainan G, et al. Safety and efficacy outcomes 3 years after switching to belatacept from a calcineurin inhibitor in kidney transplant recipients: results from a phase 2 randomized trial. Am J Kidney Dis. 2017;69(5):587-94.

90. Malvezzi P, Fischman C, Rigault G, Jacob MC, Raskovalova T, Jouve $\mathrm{T}$, et al. Switching renal transplant recipients to belatacept therapy: results of a real-life gradual conversion protocol. Transpl Immunol. 2019;56:101207.

91. Verhoeven J, Boer K, Van Schaik RHN, Manintveld OC, Huibers $\mathrm{MMH}$, Baan CC, et al. Liquid biopsies to monitor solid organ transplant function: a review of new biomarkers. Ther Drug Monit. 2018;40(5):515-25.

92. Hurkmans DP, Verhoeven J, de Leur K, Boer K, Joosse A, Baan $\mathrm{CC}$, et al. Donor-derived cell-free DNA detects kidney transplant rejection during nivolumab treatment. J Immunother Cancer. 2019;7(1):182.

93. Leibler C, Matignon M, Moktefi A, Samson C, Zarour A, Malard $\mathrm{S}$, et al. Belatacept in renal transplant recipient with mild immunologic risk factor: a pilot prospective study (BELACOR). Am J Transplant. 2019;19(3):894-906.

94. Parsons RF, Zahid A, Bumb S, Decker H, Clifford Sullivan $\mathrm{H}$, Lee FE, et al. The impact of belatacept on third party HLA alloantibodies in highly sensitized kidney transplant recipients. Am J Transpl. 2019. https://doi.org/10.1111/ajt.15585 (Epub 27 Aug 2019).

95. Ulloa CE, Anglicheau D, Snanoudj R, Scemla A, Martinez F, Timsit MO, et al. Conversion from calcineurin inhibitors to belatacept in HLA-sensitized Kidney transplant recipients with low-level donor-specific antibodies. Transplantation. 2019;103(10):2150-6.

96. Gupta G, Regmi A, Kumar D, Posner S, Posner MP, Sharma A, et al. Safe conversion from tacrolimus to belatacept in high immunologic risk kidney transplant recipients with allograft dysfunction. Am J Transpl. 2015;15(10):2726-31.

97. Crespo E, Bestard O. Biomarkers to assess donor-reactive T-cell responses in kidney transplant patients. Clin Biochem. 2016;49(4-5):329-37.

98. de Graav GN, Hesselink DA, Dieterich M, Kraaijeveld R, Douben $\mathrm{H}$, de Klein A, et al. An acute cellular rejection with detrimental outcome occurring under belatacept-based immunosuppressive therapy: an immunological analysis. Transplantation. 2016;100(5):1111-9.

99. van Besouw NM, Yan L, de Kuiper R, Klepper M, Reijerkerk D, Dieterich $\mathrm{M}$, et al. The number of donor-specific IL-21 producing cells before and after transplantation predicts kidney graft rejection. Front Immunol. 2019;10:748.
100. van der Zwan M, Baan CC, Colvin RB, Smith RN, White RA, Ndishabandi D, et al. Immunomics of renal allograft acute t cellmediated rejection biopsies of tacrolimus- and belatacept-treated patients. Transpl Direct. 2019;5(1):e418.

101. Cortes-Cerisuelo M, Laurie SJ, Mathews DV, Winterberg $\mathrm{PD}$, Larsen $\mathrm{CP}$, Adams AB, et al. Increased pretransplant frequency of CD28 + CD4 + TEM predicts belatacept-resistant rejection in human renal transplant recipients. Am J Transpl. 2017;17(9):2350-62.

102. Espinosa J, Herr F, Tharp G, Bosinger S, Song M, Farris AB 3rd, et al. CD57(+) CD4 T cells underlie belatacept-resistant allograft rejection. Am J Transpl. 2016;16(4):1102-12.

103. Krummey SM, Cheeseman JA, Conger JA, Jang PS, Mehta AK, Kirk AD, et al. High CTLA-4 expression on Th17 cells results in increased sensitivity to CTLA-4 coinhibition and resistance to belatacept. Am J Transpl. 2014;14(3):607-14.

104. de Graav GN, Hesselink DA, Dieterich M, Kraaijeveld R, Weimar W, Baan CC. Down-regulation of surface CD28 under belatacept treatment: an escape mechanism for antigen-reactive T-Cells. PLoS One. 2016;11(2):e0148604.

105. Kraaijeveld R, de Graav GN, Dieterich M, Litjens NHR, Hesselink DA, Baan CC. Co-inhibitory profile and cytotoxicity of CD57(+) PD-1(-) T cells in end-stage renal disease patients. Clin Exp Immunol. 2018;191(3):363-72.

106. Kannegieter NM, Hesselink DA, Dieterich M, de Graav GN, Kraaijeveld R, Baan CC. Differential T cell signaling pathway activation by tacrolimus and belatacept after kidney transplantation: post hoc analysis of a randomised-controlled trial. Sci Rep. 2017;7(1):15135.

107. van der Zwan M, Hesselink DA, Clahsen-van Groningen MC, Baan CC. Targeted proteomic analysis detects acute T cell-mediated kidney allograft rejection in belatacept-treated patients. Ther Drug Monit. 2019;41(2):243-8.

108. Poirier N, Blancho G, Vanhove B. A more selective costimulatory blockade of the CD28-B7 pathway. Transpl Int. 2011;24(1):2-11.

109. Liu D, Krummey SM, Badell IR, Wagener M, Schneeweis LA, Stetsko DK, et al. 2B4 (CD244) induced by selective CD28 blockade functionally regulates allograft-specific CD8 $+\mathrm{T}$ cell responses. J Exp Med. 2014;211(2):297-311.

110. Suntharalingam G, Perry MR, Ward S, Brett SJ, Castello-Cortes $\mathrm{A}$, Brunner MD, et al. Cytokine storm in a phase 1 trial of the anti-CD28 monoclonal antibody TGN1412. N Engl J Med. 2006;355(10):1018-28.

111. Eastwood D, Findlay L, Poole S, Bird C, Wadhwa M, Moore $\mathrm{M}$, et al. Monoclonal antibody TGN1412 trial failure explained by species differences in CD28 expression on CD4 + effector memory T-cells. Br J Pharmacol. 2010;161(3):512-26.

112. Shi R, Honczarenko M, Zhang S, Fleener C, Mora J, Lee SK, et al. Pharmacokinetic, pharmacodynamic, and safety profile of a novel anti-CD28 domain antibody antagonist in healthy subjects. J Clin Pharmacol. 2017;57(2):161-72.

113. Poirier N, Blancho G, Hiance M, Mary C, Van Assche T, Lempoels $\mathbf{J}$, et al. First-in-human study in healthy subjects with FR104, a pegylated monoclonal antibody fragment antagonist of CD28. J Immunol. 2016;197(12):4593-602.

114. Poirier N, Dilek N, Mary C, Ville S, Coulon F, Branchereau J, et al. FR104, an antagonist anti-CD28 monovalent fab' antibody, prevents alloimmunization and allows calcineurin inhibitor minimization in nonhuman primate renal allograft. Am J Transpl. 2015;15(1):88-100.

115. Ville S, Poirier N, Branchereau J, Charpy V, Pengam S, NerriereDaguin V, et al. Anti-CD28 antibody and belatacept exert differential effects on mechanisms of renal allograft rejection. J Am Soc Nephrol. 2016;27(12):3577-88.

116. Suchard SJ, Davis PM, Kansal S, Stetsko DK, Brosius R, Tamura J, et al. A monovalent anti-human CD28 domain 
antibody antagonist: preclinical efficacy and safety. J Immunol. 2013;191(9):4599-610.

117. Krueger GG. Selective targeting of T cell subsets: focus on alefacept - a remittive therapy for psoriasis. Expert Opin Biol Ther. 2002;2(4):431-41.

118. Sanders ME, Makgoba MW, Sharrow SO, Stephany D, Springer TA, Young HA, et al. Human memory T lymphocytes express increased levels of three cell adhesion molecules (LFA-3, CD2, and LFA-1) and three other molecules (UCHL1, CDw29, and Pgp-1) and have enhanced IFN-gamma production. J Immunol. 1988;140(5):1401-7.

119. Rostaing L, Charpentier B, Glyda M, Rigotti P, Hettich F, Franks $\mathrm{B}$, et al. Alefacept combined with tacrolimus, mycophenolate mofetil and steroids in de novo kidney transplantation: a randomized controlled trial. Am J Transpl. 2013;13(7):1724-33.

120. Amevive (alefacept) voluntarily discontinued in the U.S. Available at: https://www.psoriasis.org/media/press-releases/amevi ve-alefacept-voluntarily-discontinued-us. Accessed 19 Jun 2019.

121. Grewal IS, Flavell RA. CD40 and CD154 in cell-mediated immunity. Annu Rev Immunol. 1998;16:111-35.

122. Bingaman AW, Pearson TC, Larsen CP. The role of CD40L in T cell-dependent nitric oxide production by murine macrophages. Transpl Immunol. 2000;8(3):195-202.

123. Larsen CP, Pearson TC. The CD40 pathway in allograft rejection, acceptance, and tolerance. Curr Opin Immunol. 1997;9(5):641-7.

124. Karnell JL, Rieder SA, Ettinger R, Kolbeck R. Targeting the CD40-CD40L pathway in autoimmune diseases: humoral immunity and beyond. Adv Drug Deliv Rev. 2019;141:92-103.

125. Kirk AD, Burkly LC, Batty DS, Baumgartner RE, Berning JD, Buchanan K, et al. Treatment with humanized monoclonal antibody against CD154 prevents acute renal allograft rejection in nonhuman primates. Nat Med. 1999;5(6):686-93.

126. Pearson TC, Trambley J, Odom K, Anderson DC, Cowan S, Bray $\mathrm{R}$, et al. Anti-CD40 therapy extends renal allograft survival in rhesus macaques. Transplantation. 2002;74(7):933-40.

127. Schuler W, Bigaud M, Brinkmann V, Di Padova F, Geisse S, Gram H, et al. Efficacy and safety of ABI793, a novel human anti-human CD154 monoclonal antibody, in cynomolgus monkey renal allotransplantation. Transplantation. 2004;77(5):717-26.

128. Kanmaz T, Fechner JJ Jr, Torrealba J, Kim HT, Dong Y, Oberley TD, et al. Monotherapy with the novel human anti-CD154 monoclonal antibody ABI793 in rhesus monkey renal transplantation model. Transplantation. 2004;77(6):914-20.

129. Boumpas DT, Furie R, Manzi S, Illei GG, Wallace DJ, Balow JE, et al. A short course of BG9588 (anti-CD40 ligand antibody) improves serologic activity and decreases hematuria in patients with proliferative lupus glomerulonephritis. Arthritis Rheum. 2003;48(3):719-27.

130. Zhang T, Pierson RN 3rd, Azimzadeh AM. Update on CD40 and CD154 blockade in transplant models. Immunotherapy. 2015;7(8):899-911.

131. Song L, Ma A, Dun H, Hu Y, Zeng L, Bai J, et al. Effects of ASKP1240 combined with tacrolimus or mycophenolate mofetil on renal allograft survival in Cynomolgus monkeys. Transplantation. 2014;98(3):267-76.

132. Vincenti F, Klintmalm G, Yang H, Peddi VR, Blahunka P, Conkle $\mathrm{A}$, et al. A randomized, phase $1 \mathrm{~b}$ study of the pharmacokinetics, pharmacodynamics, safety, and tolerability of bleselumab, a fully human, anti-CD40 monoclonal antibody, in kidney transplantation. Am J Transplant. 2019. https://doi.org/10.1111/ajt.15560 (Epub 9 Aug 2019).
133. Harland R, Klintmalm G, Jensik S, Yang H, Bromberg J, Holman J, Kumar MAnil, Santos V, Larson T, Wang X. Efficacy and safety of Bleselumab in kidney transplant recipients: a phase 2, randomized, open-label study (abstract). 2019. https://atcme etingabstracts.com/abstract/efficacy-and-safety-of-bleselumab -in-kidney-transplant-recipients-a-phase-2-randomized-openlabel-study/. Accessed 4 Jul 2019.

134. Cordoba F, Wieczorek G, Audet M, Roth L, Schneider MA, Kunkler A, et al. A novel, blocking, Fc-silent anti-CD40 monoclonal antibody prolongs nonhuman primate renal allograft survival in the absence of B cell depletion. Am J Transpl. 2015;15(11):2825-36.

135. Nashan B, Tedesco H, van den Hoogen MW, Berger SP, Cibrik D, Mulgaonkar S, et al. CD40 inhibition with CFZ533-a new, fully human, non-depleting, $\mathrm{Fc}$ silent $\mathrm{mAB}$-improves renal allograft function while demonstrating comparable efficacy vs. tacrolimus in de-novo CNI-free kidney transplant recipients. Transplantation. 2018;102:S366.

136. Page A, Srinivasan S, Singh K, Russell M, Hamby K, Deane T, et al. CD40 blockade combines with CTLA4Ig and sirolimus to produce mixed chimerism in an MHC-defined rhesus macaque transplant model. Am J Transpl. 2012;12(1):115-25.

137. Gilson CR, Milas Z, Gangappa S, Hollenbaugh D, Pearson TC, Ford ML, et al. Anti-CD40 monoclonal antibody synergizes with CTLA4-Ig in promoting long-term graft survival in murine models of transplantation. J Immunol. 2009;183(3):1625-35.

138. Larsen CP, Elwood ET, Alexander DZ, Ritchie SC, Hendrix R, Tucker-Burden C, et al. Long-term acceptance of skin and cardiac allografts after blocking CD40 and CD28 pathways. Nature. 1996;381(6581):434-8.

139. Zhu P, Chen YF, Chen XP, Li D, Cheng Q, Huang ZY, et al. Mechanisms of survival prolongation of murine cardiac allografts using the treatment of CTLA4-Ig and MR1. Transpl Proc. 2008;40(5):1618-24.

140. Pinelli DF, Wagener ME, Liu D, Yamniuk A, Tamura J, Grant $\mathrm{S}$, et al. An anti-CD154 domain antibody prolongs graft survival and induces Foxp3(+) iTreg in the absence and presence of CTLA-4 Ig. Am J Transpl. 2013;13(11):3021-30.

141. Engela AU, Baan CC, Litjens NH, Franquesa M, Betjes MG, Weimar W, et al. Mesenchymal stem cells control alloreactive $\mathrm{CD} 8(+) \mathrm{CD} 28(-) \mathrm{T}$ cells. Clin Exp Immunol. 2013;174(3):449-58.

142. Hoogduijn MJ, Betjes MG, Baan CC. Mesenchymal stromal cells for organ transplantation: different sources and unique characteristics? Curr Opin Organ Transpl. 2014;19(1):41-6.

143. Belatacept Product Monograph. 2019. https://www.ema.europ a.eu/en/documents/product-information/nulojix-epar-productinformation_en.pdf. Accessed 8 Aug 2019.

144. Klaasen RA, Egeland EJ, Chan J, Midtvedt K, Svensson M, Bolstad N, et al. A fully automated method for the determination of serum belatacept and its application in a pharmacokinetic investigation in renal transplant recipients. Ther Drug Monit. 2019;41(1):11-8.

145. Vincenti F, Blancho G, Durrbach A, Grannas G, Grinyo J, MeierKriesche HU, et al. Ten-year outcomes in a randomized phase II study of kidney transplant recipients administered belatacept 4-weekly or 8-weekly. Am J Transpl. 2017;17(12):3219-27.

146. Eikmans M, Gielis EM, Ledeganck KJ, Yang J, Abramowicz D, Claas FFJ. Non-invasive biomarkers of acute rejection in kidney transplantation: novel targets and strategies. Front Med (Lausanne). 2018;5:358. 